\title{
Policy Framework of Small and Micro Enterprises and Its Role on the Development of the Sector in Bahir Dar City, Ethiopia
}

\author{
Getnet Hunegnaw Kebede \\ Department of Management, College of Business and Economics, Bahir Dar University
}

\begin{abstract}
It is obvious that micro and small enterprises play vital roles for economic growth, job creation, and poverty reduction for a nation both in developing and developed countries across the globe in which they are the means through which accelerated economic growth and rapid industrialization have been achieved in developed countries. The purpose of this study was to assess the contribution of small and micro enterprises' strategy (policy framework) in alleviating the problems of small and micro enterprises in Bahir Dar city, Ethiopia, in particular reference to the manufacturing enterprise sub-sector. Descriptive survey method; stratified and simple random sampling technique were used. Quantitative data were collected using questionnaire containing close-ended and few open-ended questions from 138 sample respondents. Although there have been attempts by the government and other stakeholders to improve the working environment of micro and small enterprises in Bahir Dar city, based on the regression analysis result, the sector has been suffering from a number of such as availability of capital, distribution of working place access to facilities (electricity, water, telephone, etc.) and legal framework were the most dominant factors that influence the development of small and micro enterprises in Bahir Dar city respectively. Indeed, the establishment of the policy framework has been appreciated but the formulation of the policy by itself does not alleviate the problems of small and micro enterprises and could not support the development of the sectors, thus, it is concluded that the strategy of small and micro enterprises has to be implemented in a full-fledged manner to alleviate the problems that small and micro enterprises face. Finally, the result of the survey calls for concrete and coordinated regulatory and institutional support in working places, financial and extension services, provision of facilities like road, water and electricity services.
\end{abstract}

Keywords: Bahir Dar, Small and Micro Enterprises

DOI: $10.7176 / \mathrm{PPAR} / 9-4-01$

Publication date: April $30^{\text {th }} 2019$

\section{Introduction}

Micro and small enterprises are one of the tools of economic growth, job creation, and poverty reduction in a country. They have been the means through which accelerated economic growth and rapid industrialization have been achieved. While the contributions of small businesses to development are generally acknowledged, entrepreneurs face many obstacles that limit their long-term survival and development. Research on small-business development has shown that the rate of failure in developing countries is higher than in the developed world. Scholars have indicated that starting a business is a risky venture and warn that the chances of small-business owners making it past the five-year mark are very slim. The owners should develop both long-term and short-term strategies to guard against failure (Britte, 1991; Suneetha and Sankaraiah, 2014).

A positive relationship has been documented between small-business development and economic growth in developed countries. However, far less research has been conducted on this relationship in developing countries. Studies in micro and small-business development are necessary in developing countries like Ethiopia because of the dissimilarities in the process between developed and developing countries. It is also essential to understand the problems facing small-business development in developing countries because they are significantly different from those facing developed countries. These obstacles include lack of financial resources, lack of management experience, poor location, laws and regulations, general economic conditions, as well as critical factors such as poor infrastructure, corruption, low demand for products and services, and poverty (Tucker and Lean, 2003; Wagema, 2008).

On the other hand, micro and small-scale enterprises (MSEs) which are considered to be the places where those whom the economy failed to absorb take shelter in are increasingly becoming important economic actors in generating income and employment throughout Africa and other developing countries. This sector on average contributes about 67 percent employment to the total labor force in most of the developing countries (Kinyanjui, 2006).

Recognizing the indispensable role of micro and small business enterprise and private sector enterprises in general, many countries have instituted enterprise support networks and structures to stimulate the development of these enterprises. Ethiopia is no exception. At various times since the 1970s, many countries like Nigeria has designed and introduced measures to promote small-and medium-enterprise development (Akwani, 2007; Wagema, 2008). These measures have included fiscal, monetary, and export incentives. In Ethiopia, which is one of the poorest countries of the world, micro and small-enterprise sector assumes particular importance. 
This calls for special promotional movement and intervention of policy makers, researchers and other development agents in this sector to develop the potential of employment generation who tend to be the majority of the micro and small enterprise operators in Ethiopia. Having said this, the researcher examines factors that affect the development of micro and small business enterprise and review the role of MSE promotion policy for the development of the sector in particular emphasis of manufacturing enterprises in the city of Bahir Dar.

Bahir Dar, the capital city of the Amhara National Regional State, as a settlement, was the site of the church of Kidanemehiret since its identification in the $14^{\text {th }}$ century and was known as Bahir Dar Kidanemihiret. However, during the Gonderian era, it had become an important center. On the basis of oral tradition, during the reign of Iyasu (1682-1706), its site was changed to a monastery of St. Georg, instead of Bahir Dar Kidanemehiret (Mulugeta, 1996).

Two factors have contributed for the development of this village into a market and finally attaining the status of a town. First there was internal trade carried out by long distance caravan merchants. Through this rout small quantities of salt, cloth and other manufacturing goods were imported from neighboring countries like Sudan and Eritrea to Lake Tana ports such as Bahir Dar. Second, Bahir Dar had become the distribution center for the trade items to other trading centers south of it, in the rest of Gojjam region (Mulugeta, 1996).

\subsection{Statement of the Problem}

The importance of entrepreneurship in micro and small enterprises as an instrument of poverty reduction through employment creation and supply of affordable products has been implicitly and explicitly accepted by many countries and international development organizations. In Ethiopia, support to MSEs has been considered as a tool to employment creation and as a foundation to long-term development objectives. However, even though some countries are believed to be successful in fully utilizing the potential of entrepreneurs to achieve better economic development, Ethiopia is still behind in exploiting this huge potential to meet its development objectives. This research topic 'small and micro enterprises' policy framework (strategy) and the problems that hinder the development of the sector: the case of manufacturing enterprises in Bahir Dar City, Ethiopia " is, therefore, initiated from the following factual problems: Entrepreneurship, which is recognized to be a change agent and the fourth factor of production that brings together land, labor and capital, makes a significant contribution to the pace of nation's economic development. However, this important factor of production is not being utilized properly in the city. Though the crucial role played by the sector in driving economic development and job creation, it is increasingly understood and there has been little effort to promote micro and small enterprise industries let alone the strategy has been formulated because the development and the expansion is weak/slow in the study area.

\subsection{Objective of the Study}

Based on the stated problems, the objective of this study was to analyze the role of micro and small enterprises' strategy (policy framework) and to examine the problems that hinder the development of micro and small business enterprise and in the city of Bahir Dar.

\subsection{Research Questions}

Based on the above stated objective, the researcher tried to answer the following basic research questions:

I. Does the SMEs strategy (policy framework) support the development of micro and small enterprise and how much of this strategy is tailored/personalized to operators in Bahir Dar City?

II. What are the problems that hinder the development of micro and small enterprises in Bahir Dar City?

\section{Review of Related Literature}

\subsection{Definition of Small and Micro Enterprise}

In legal terms distinctions are only made between sole traders, partners and companies with no formal definition of what constitutes a micro and small business. And there is no single and universal definition of what constitutes a micro and small firm, which can be useful for all purposes. Firms differ in their levels of capitalization, sales and employment. Hence, definitions which employ measures of size (number of employees, turnover, profitability, net worth, etc.) when applied to one sector could lead to all firms being classified as small, while the same size definition when applied to a different sector could lead to a different result (Gibb, 1988). Thus, there is no single consensus agreed definition.

For instance, in the United States of America, the Small Business Administration (SBA) defines MSEs based on the number of employees, total asset and annual sales of the enterprise. Enterprises are called small family business, if they have four or fewer employees with annual sales of USD 499 or less while those having 5 to 9 employees with annual sales from USD 500 to USD 2,499 are classified as small enterprises (Rizwanul Islam, 1996)

When we see how micro and small enterprises, the Ministry of Trade and Industry (MoTI,1999 cited in Zikrehig, 2006) of Ethiopia in its micro and small enterprises development strategy defined Micro and Small 
enterprises in Ethiopia as follow:

Micro enterprises are those business enterprises with a paid-up capital of not exceeding birr 20,000, and excluding high-tech. consultancy firms and other high-tech. establishments and small enterprises are those business enterprises with a paid-up capital of above 20,000 and not exceeding birr 500,000, and excluding high tech. consultancy firms and other high tech. establishments.

\subsection{Theories on the Origin of Small and Micro Enterprises}

The idea of micro and small enterprise, which stems from the concept of entrepreneurship, has got wider attention and recognition after the ILO mission (1972) as cited in Gebrehiowt and Wolday (2004) on employment, income and equality in Kenya. Since then it has become a debatable issue about its concepts and definitions. The theoretical explanations about MSE origin and development are briefly discussed as follows.

I. Labor Supply and Urban MSEs: This theory relates the origin of MSEs to the growth of labor force (unemployment) beyond the labor demand of the formal economic sector. It implies that micro and small enterprises are developed for the final work place of people who are unable to find a job in the formal economies. That means the urban micro and small enterprise grow when the larger economic sector contracts very slowly to absorb the labor force (Arinaitwe, 2006). When formal economic sector expands, it contracts and thus develops anticyclically to the formal economy implying the inverse relationship between the development of micro and small enterprise and formal economic sector.

Although this explanation has some factual basis, the researcher would like to comment on it three reasons. First, empirical evidence from many developing countries show that micro and small enterprises have existed at all times, irrespective of the availability of or loss of employment in the formal economic sector. Even when these enterprises expanded medium and large -scale enterprise or disappear, other new MSEs have emerged from the society. Second, the explanation generalizes as if all micro and small enterprises are easily accessible, as the final work place for anyone who cannot find a job in the better economic sector. But in reality, all are not easily accessible, as many business activities need even little capital, skill, and knowledge. The third one is people's choice in expectation of profitability and comparative advantages in skills of business. For instance, some people who have grown with the micro and small enterprise inherit the skill of business activity from their family or trained in the activity, do not leave it when they are employed in the formal economic sector that they like their own job and business with the hope of expanding it. The study conducted by Gebrehiwot and Wolday (2004) in Ethiopia, attests this reality as the MSE entrepreneurs join the sector due to the activities, lack of other alternatives, parents/relatives are/were in the activities and the like.

II) Output -Demand and the Urban Small and Micro Enterprise Sector: According to this theory a prerequisite for the development of MSE is the presence of markets for their products or services. MSEs have developed positively with the economy as a whole. This theory implies that MSEs have existed and developed as the formal economic sector has developed. That is, there is demand for their products or services and there are supplies want to do these activities (Arinaitwe, 2006). The researcher agrees with this idea. If there is no demand for their product or service, MSEs could not have survived in the economic system.

III) Commercialization of the rural areas and SMEs: With respect to this theory, commercialization of rural areas leaves many farmers without land and they are forced either to migrate to urban centers or engage in non-farm economic activities in rural areas to earn their living. Of course, rural -urban migration due to commercialization of the rural areas may have impacts on both emergence of MSEs and the creation of demand for their products or services since migrated people may have some money earned from the sale of land or the compensation lands. However, rural - urban migration in the case of most developing countries, especially in Ethiopia occurs not due to commercialization of rural areas but due to environmental hazards, sever rural poverty and lack of agricultural land. Hence, in the short run, the migrated people have little or no contribution to the emergence of MSEs since they do not have anything to work with. Rather they become a burden to the urban economy. But in the long run, the MSEs not only become a temporary but also a permanent work place for many poor rural-urban migrants (Arinaitwe, 2006). To conclude, MSEs are not the result of a certain stage of mode of production in the socioeconomic progress of the society, rather they have been part of the economy as a whole and have existed for centuries serving the society. They existed because there are many people who earn their living by doing these activities and there are also demands for their products/services. Although MSEs vary in the dimension of the business, in their capital, in the size of employment, in the type of business and in their production, they are found in all societies of developed and developing countries. They are part and parcel of the system. It is only their magnitude which is viable (Arinaitwe, 2006).

\subsection{The Strategy of Small and Micro Enterprises Development of Ethiopia}

By virtue of their size, location and their capacity to create employment, MSEs have proved their undeniable effect for rapid economic growth. Cognizant of this fact, the Ethiopian governments has given particular attention to the development of the sector and has formulated a National micro and small enterprises Development and 
Promotion Strategy, which enlightens a systematic approach to alleviate the problems and promote the growth of micro and small enterprises. The strategy paper is first prepared at national level and then each region adapted its own strategy paper on the basis of the national strategy, after synchronizing with the prevailing conditions of the region. The national micro and small enterprises strategy paper is issued in 1997 while that of the Amhara region is issued in 2001 (Federal Micro Small Enterprises Development Agency and Regional Micro and Small Enterprises Development Agency).

\section{Research Methodology}

\subsection{Design of the Study}

In this study the researcher uses descriptive survey design method since he employs questionnaire and interview to collect the necessary data from the sample respondents and hence this method is appropriate to collect data related to factors affecting a certain activity, opinion about service, etc and is preferred to examine what is going on' and to enhance the validity of the results of this study, the researcher used both qualitative and quantitative research approach.

\subsection{Sampling Technique and Sample Size}

The researcher used stratified and simple random sampling technique for the study. Because Stratification; selecting strata and then a sample respondent from each stratified area has the advantage of cost effectiveness, providing representative and reliable data, facilitating revisit or asking supplemental questions about the previous responses and monitoring the progress of the work except its complication disadvantage during analysis. The researcher takes 138 (approximately 32 percent of 438 enterprises) manufacturing enterprise randomly using lottery method of sampling from the selected areas.

\subsection{Source and Methods of Data Collection}

As the approach is both qualitative and quantitative, different data collection techniques are adopted for this study. Both primary and secondary source of data is used. Close-ended five -point Likert scale items and few open -ended questionnaires and interviews were administered to the sample respondent so as to appraise various attributes and draw conclusions which is generalized for the city as a whole. To collect the secondary data, relevant books, officials' documents as well as web sites were consulted. In this regard, the reliability of the measurement items was checked using Cronbach's alpha value and consultation of experts and all the Cronbach's alpha coefficients were greater than .70 (Nunnally, 1978) and is presented in the following table.

\section{Table 1: Cronbach's alpha Value}

\begin{tabular}{|l|l|l|l|}
\hline Variables & No. of items & Cronbach's alpha Value & Remark \\
\hline Entrepreneurial Skill & 4 & 0.72 & Valid \\
\hline Business Record & 3 & 0.76 & Valid \\
\hline Access to working place & 3 & 0.78 & Valid \\
\hline Access to Facilities & 4 & 0.80 & Valid \\
\hline Raw Materials & 3 & 0.74 & Valid \\
\hline Access to Market & 3 & 0.77 & Valid \\
\hline Availability of Capital & 3 & 0.86 & Valid \\
\hline Legal Framework & 4 & 0.82 & Valid \\
\hline Development of SMEs & 3 & 0.76 & Valid \\
\hline
\end{tabular}

\subsection{Statistical tools}

Once the data is collected, the next task is to process it and analyses taking into account the objectives of the study. The data from questionnaire is tabulated, organized and analyzed using multiple regression analysis and descriptive statistics techniques. Coefficient of determination (R2) standardized beta coefficients, frequency and percentages were used for the purpose of interpretation of the results.

\section{Results and Discussions}

\subsection{Inferential Statistics: Regression Analysis}

Before running the regression analysis, the assumptions of regression analysis such as the normality of data, linearity of the variables and the multicollinearity of the variables were checked. The data is normal and there is no multicollinearity problem since the tolerance and the variance inflation factor values are less than the 2 and 10 respectively (Hair et al., 2010). The researcher conducted multiple regression analysis to examine that which factor is dominantly influence the development of small and micro enterprises in Bahir Dar City. The result of the regression analysis is demonstrated in the following table. 
Table 2: Multiple Regression Analysis

\begin{tabular}{|l|l|l|l|}
\hline Explanatory Variables & Unstandardized $B$ coefficients & T-value & P-value \\
\hline Training and entrepreneurial skill & 0.221 & 2.354 & 0.002 \\
\hline Business record & 0.028 & 2.006 & 0.036 \\
\hline Distribution of working place & 0.586 & 3.646 & 0.000 \\
\hline Access to facilities & 0.462 & 3.260 & 0.003 \\
\hline Raw materials & 0.036 & 2.026 & 0.042 \\
\hline Access to market & 0.042 & 2.048 & 0.022 \\
\hline Availability of capital & 0.681 & 3.824 & 0.000 \\
\hline Legal framework (taxation) & 0.323 & 2.682 & 0.005 \\
\hline$R^{2}$ & & \\
Adjusted R & & \\
F-value (Sig.) & & \\
\hline
\end{tabular}

From the table above, it is found that all the stated variables have their own influence on the development of small and micro enterprises in Bahir Dar City as confirmed by the regression model of F-value (221.172, $\mathrm{p}<0.05$ ); and the explanatory variables have a variance of $78.6 \%$ on the development of small and micro enterprises where as the remaining $21.4 \%$ of the variance is explained by other factors which were not included in this study. Similarly, from the regression analysis, availability of capital $(B=0.681, p=0.000, t=3.824)$, access to working place $(\mathrm{B}=0.586, \mathrm{p}=0.000, \mathrm{t}=3.646)$, access to facilities (electricity, water, telephone, etc. $)(\mathrm{B}=0.462$, $\mathrm{p}=0.003, \mathrm{t}=3.260)$; and legal framework $(\mathrm{B}=0.323, \mathrm{p}=0.005, \mathrm{t}=2.682)$ were the most dominant predictors that influence the development of small and micro enterprises in Bahir Dar city respectively.

\subsection{Descriptive statistics: Frequency and Percentage}

Besides the regression analysis, the researcher used descriptive statistics such as frequency and percentage to analyze the problems of small and micro enterprises; and thus, the following points have revealed. About 75 (54.35 percent of) respondents are migrants who come to Bahir Dar that constitutes 62.67 percent of rural in their origin to find job, for education, to live with relatives and job transfer in that order. Thus, MSEs are the major source of employment for young and unemployed people in the study area.

Most (82.61 percent of) respondents attested that lack of alternative employment opportunity was the major reason to join in their respective activity. For the others, needing for additional income for their families and displacement of families in order of importance are the main reasons for entrepreneurs to join the sector.

Most (77.14 percent) of the respondents are self-taught to acquire the skill and they have started the business by their own initiative. For others, they develop their skill through on job training, from family, and from formal training and encouraged by family, friends and MSE officials to start their business. This clearly shows that there is a problem in the implementation of the MSE policy even though most the enterprises are established after the adoption of the policy.

Most (66.67 percent) of respondents do not record their business activities due to the reason of business too small as they explained. Thus, they are handicapped to evaluate the performances and future prospects of their enterprises, which requires for business trainings to create awareness and to promote the development of the sector.

With regard to working place, most (56.51 percent) of respondents operated in rented places and 57.25 percent of them pay a monthly rent of birr 501- 1000. This affects the amount of saving as respondents explained and which tends to force many of them to operate their business inaccessible, unsuitable and unsanitary working conditions with limited or no supportive facilities.

Most of the sample respondents replied that there is a problem of distributing working places for individuals due to biasness towards relatives, friends and due to the problem of corruption and political affiliation.

Only 18.12 percent of the respondents have access to all facilities (water, electricity, telephone, etc.) although availability of infrastructure is one of the determinant factors for the development of micro and small enterprise. This is also confirmed by the majority ( 51.45 percent) of respondents as their working place is not suitable.

The majority ( 52.90 percent) of the respondents obtain the raw materials/inputs from whole sellers. The major customers for most ( 80.43 percent of) the sample respondents are consumers; while others sell their products for two or three types of customers implying the existence of limited outlets for their products.

Currently, most of micro and small enterprise operators have been limited by shortage of work place (47.10 percent), heavy government taxes and regulations (44.20 percent), lack of working capital and lack of market in order of importance.

The most important source of initial capital was own saving, credit from relatives/friends and assistance from 
relatives/friends which account together 57.25 percent, and loan from micro and small finance institutions in that order, which lead to self-finance with small amount of capital, income and savings.

Only 6.52 percent and 5.8 percent of the sample respondents received formal training before and after joining their respective activities respectively. This implies that encouragement and formal trainings from the responsible agency is yet insignificant due to its infancy stage. Lack of entrepreneurial skill is indicated by the respondents as their problem to start and operate their activities. 44.20 percent of the respondents rank high tax/government regulation as the second major problems that affect the current operation of their activities.

The government has tried to identify and apply appropriate regulations, and has engaged in a consultation process through its strategy of small and micro enterprise. However, according to the study, most of the sample respondents reported problems related to taxation, land distribution and credit facilities. This implies that there is no coordination among revenue office, land administration authority, financial institutions and micro and small enterprises development agency in the city. That means the respondents strongly criticize the lending policies of financial institutions and the provision of working places.

54.35 percent of the sample respondents attested about discouraging attitudes of government, NGOs and other local authorities towards their activities, while 28.98 percent of the respondents supported their neutrality. However, a proportion of the respondents (16.67 percent) explained their supportive attitude. According to their response, some government institutions and NGOs have provided them support in facilitating provision of working places, credit facilities, business and technical trainings, advisory and counseling services and preparing trade fairs and exhibitions.

\section{Conclusions and Policy Implications 5.1 Conclusions}

In order to alleviate the problems of small and micro enterprise in Bahir Dar and to support the existing business community and to facilitate the creation of new business environment that focused on the unemployed individuals, the micro and small enterprises' development agency in collaboration with Bahir Dar city administration has designed a directive. However, the results of this study showed that there is divergence between directives issued and the actual implementation in the ground. Thus, based on this, the researcher has drawn the following conclusions.

Reasons to Join the Sector: As the literature review shows, individuals join to micro and small enterprise activities to escape from poverty and need for small capital and limited skill. The finding also indicates, 82.6 percent of respondents stated lack of employment as the major reason to join micro and small enterprise activity. This indicated that employment and income generation is one of the roles of the development the micro and small enterprises and it is coincided with the theory of labor supply/unemployment and urban MSEs (MSEs is mainly the result of unemployment in the formal economies) as discussed in the literature review section of the study.

Origin of Respondents: Commercialization of the rural areas is one of the approaches that can cause for the establishment of micro and small enterprises. In this respect, the finding of the study shows that the origin of most of the respondents are from rural but the reasons to leave their place is not due to the commercialization of their rural areas rather to find job and through time they start and operate MSEs activities in the city.

Access to Capital and Credit: Access to capital and credit such as loan from different sources, access for start-up capital, source of working capital, loan amount and loan processing/repayment time is one of the essential elements for the development of micro and small enterprise. However, most of the respondents revealed that lack of initial capital, short repayment period, problem of collateral and high interest rate as the major factors that affect the development of the sector and hence the major source of capital for most of the respondents is own saving and credit from relatives/friends.

Provision of Work Place: To make micro and small enterprise operators profitable and to enhance the development of the sector, provision of work place indispensable. But the finding of the study indicates that lack of work place is the major problem to operate since most of the respondents operate their respective enterprises in rented places and this affects the growth of their enterprises and their saving condition.

Infrastructure Facilities: As so many authors confirmed, availability of infrastructure facilities such as, telephone, electricity, transport and water supply situations are the determinant factors for the development of micro and small enterprises. Even though there is no exaggerate problem of such facilities, a portion of respondents replied that lack of water facility is one of their problem.

Legal Frameworks: Micro and small enterprise development strategy/policy incorporates a number of principles to support MSEs entrepreneurs, however, the finding shows major problems related to government rules and regulations such as assessment of tax/high tax, credit policy/no sufficient source of finance and land distribution procedures of the municipality. Besides, the attitude of government and society towards entrepreneurs and business development facilities related factors is included in the survey analysis.

Role of Government and Other Stakeholder: Although there have been attempts by the government and other stakeholders to improve the working environment of micro and small enterprises in Bahir Dar city and also most of 
the enterprises are established after the strategy of MSE is issued in 2001, the sector have been suffering from a number of factors that affect its development such as lack of initial/working capital, lack of working place, unfavorable policy frameworks mainly of high tax and arbitrary tax administrative systems, lack of market, lack of business skill and information are the major problems that affect the development of the sub-sector.

\subsection{Policy Implications}

Based on the results obtained and conclusions drawn from the data analysis and interpretation, the researcher forwards the following recommendations.

Access to Initial and Current Capital: In order to solve the problem of initial and current capital, the micro and small enterprises agency should make revisions on the lending policies; raise the lending ceiling of micro and small finance loans to better accommodate entrepreneurs in MSEs; reduce bureaucratic procedure; adopt flexible repayment arrangements, reduce collateral requirements, group lending and high interest rate; provide necessary information where and how entrepreneurs can approach the financial institutions; expand alternative financial source /options of financial institutions such as credit and saving associations and cooperatives of the society; conduct government commercial Bank discussions for enabling Bank to finance micro and small enterprise operators.

Work Place: To alleviate the problem of working place, the city government and other stakeholders should encourage local officials to allocate land for entrepreneurs; encourage the creation of common facility centers to display their products; provide working premises as incentives for successful entrepreneurs.

Legal Framework: To avoid the problem related to taxation, the following remedial actions should be taken by the micro and small enterprise development agency, revenue office and other concerned government authorities review practices affecting entrepreneurs including corruption.

Involvement of Women: To alleviate the problems related to low participation of women in MSEs; the micro and small enterprises development agency, women entrepreneurs' association and other concerned institutions should provide training and advisory services for female to enhance the engagement of them in micro and small enterprise activities to minimize women unemployment.

Problems of Market: To minimize problems related to lack of market and/or demand for products; the micro and small enterprise development agency, and other concerned institutions in coordination with entrepreneurs should provide training and advisory services to assist entrepreneurs in identifying markets and new potential business areas, pricing system, demand based production and how to handle and approach their customers; and to strengthen the started exhibitions, bazaars and periodical street trade fairs.

Entrepreneurial Skill: To achieve all the above recommendations, micro and small enterprise should assign a coordinating sector for business development system services in its office and to encourage and support WEA in its effort to enhance the involvement of female in micro and small enterprise and provide other business information through their membership networks and initiate the formation of other business-oriented organizations.

Finally, there can be many recommendations that can benefit the micro and small enterprises sector as a whole. But first of all, Bahir Dar city administration should understand the bottlenecks that hinder the development of small and micro enterprise in each sub-city to better identify the problems of each sector and should give priority according the problems. On the other hand, what is by far the most important is improving administrative and service provision mechanisms in each sub-city through the formulation of rules and regulations that support the development of the sector; and also, Bahir Dar city administration would be better to put into practice the already established small and micro enterprise development policy of the country.

\subsection{Limitation and Further Research}

The research is not comprehensive. It does not cover all sectors of the small and micro enterprises in Bahir Dar City administration, Amhara Region. Hence, other researchers have to conduct same research in a comprehensive manner by incorporating other sub-sectors to better identify the problems of the sectors in the region and to compare the problems of each sector.

\section{References}

Abreham Tekeste and Hannah van der Deijl (2005). Characteristics and Determinants of Unemployment and Underemployment in Ethiopia, ILO, Geneva.

Amhara Micro and Small Enterprises Development Agency (2001). Micro and Small Enterprises Development Strategy. Bahir Dar, Ethiopia.

ZikreHig (2006). Amhara National Regional State Micro and Small Enterprises and Industry Works Promotion Agency Establishment Proclamation, No. 122/2006.Bahir Dar: Ethiopia.

Amhara Trade, Industry and Urban Development Bureau (2004). Concept Paper for the Formulation of Private Sector Capacity Building Program in Amhara National Regional State. Bahir Dar, Ethiopia.

Andualem Tegegne (1997). Small-Scale Enterprise and Entrepreneurship Developmentin Ethiopia: Concepts, 
Definitions and Major Issues, Small-Scale Enterprise Development in Ethiopia. Proceedings of the Sixth Annual Conference on the Ethiopian Economy, Addis Ababa.

Arinaitwe, J. K. (2006). Factors Constraining the Growth and Survival of Small Scale Businesses: A Developing Countries Analysis. Journal of American Academy of

Business, 8(2), 167-178.

Assefa Admassie (1997). A Comparative Analysis of the Development of Small Scale Industries in Region 14 with Other Regions, in Small-Scale Enterprise Development in Ethiopia. Proceedings of the Sixth Annual Conference on the Ethiopian Economy, Addis Ababa.

Bahir Dar City Administration Business plan (2008). Document of Micro and Small Enterprises.Office of Micro and Small Enterprise, unpublished, Bahir Dar.

Bandura. O.M. S (1997). Micro and Small Enterprise Potential for Development: General Considerations, Economic and Social Research Foundation, Dare -Selam.

Brigitte Berger (1991). The Culture of Entrepreneurship: The Institute for Contemporary Studies, San Francisco: Mc Graw-Hill. (Central Statistics Authority) CSA (2003). Reports on Small Scale Manufacturing Industries Survey. Statistical Bulletin, Addis Ababa.

Central Statistics Authority (2007). National population Census, Results for the Amhara Region. Addis Ababa.

Daniels, L. (1999). The Role of Small Enterprises in the Household and National Economy in Kenya: A Significant Contribution or a Last Resort? World Development, 27 (1):55-65

Ducker Peter. (1985). The Discipline of Innovation, Harvard Business Review, USA.

Gebrehiwot Ageba and Wolday Amha (2004). Micro and Small and Enterprises Development in Ethiopia: Survey Research Report II, Ethiopia Development Research Institute, Addis Ababa Ethiopia.

Gibb Andrew (1988). Graduate Career Aspirations, Education and Entrepreneurship: Some Research Findings, New Jersey.

Harabi, Najib (2003). Determinants of Firm Growth: An Empirical Analysis from Morocco. Solothurn University of Applied Science, North-western Switzerland. Klaus

Haftendorn and Carmala Salzano (2004). Facilitating Youth Entrepreneurship, Part II, A Directory of Awareness and Promotion Programs in Formal and Non-Formal Education, SEED working paper No. 59, ILO.

Kinyanjui, M. N. (2006). Overcoming Barriers to Enterprise Growth: The Experience of MSEs in Rural Central Kenya. Nairobi, Kenya.

k. Suneetha and T.Sankaraiah, (2014). Problems of MSMEs and Entrepreneurs inKadapa District. Journal of Economics and Finance, 3 (2), 31-37.

Malecki (1994). The Psychology of the Entrepreneur. In D.L. Sexton and R.W. Ministry of Trade and Industry (1997). Micro and Small Enterprises Development Strategy, Addis Ababa, Ethiopia.

Mulugeta Worku (1996). A Geographical Study of Social and Economic Infrastructure in Bahir Dar Town, Unpublished Thesis, Addis Ababa University.

Rizwanul Islam (1996). Small and Micro Enterprises in a Period of Economic Liberalization: Opportunities and Challenges, ILO, New Delhi.

Seleshi Lemma (2001). Subcontracting Strategy for the Ethiopian Micro and Small Enterprises, Ethio-German Micro and Small Enterprises Development Program, Addis Ababa, Ethiopia.

Simon White and Peter Kenyon (2001). Enterprise Based Youth Employment Policies, Strategies and Programs. Skills Working paper No. 1, ILO, Geneva.

Tucker, J. and Lean, J. (2003). Small Firm Finance and Public Policy. Journal of Small Business and EnterpriseDevelopment,10 (1), 50-61.

Vasant Desai (1997). Dynamics of Entrepreneurial Development and Management, Mumbai: Himalaya Publishing.

Wagema G. M. (2008). Determinants of Access to Bank Credit by Micro and Small Enterprises in Kenya. Growing Inclusive Markets Conference. Kenya. 